\title{
Review of Climate Change Impacts on Human Environment: Past, Present and Future Projections
}

\author{
Nasrat Adamo1, Nadhir Al-Ansari2 ${ }^{*}$, Varoujan Sissakian ${ }^{3}$ \\ ${ }^{1}$ Consultant Engineer, Norrköping, Sweden \\ ${ }^{2}$ Lulea University of Technology, Lulea, Sweden \\ ${ }^{3}$ Department of Natural Resource Engineering and Management, University of Kurdistan Hewler, KRG, Iraq \\ Email: nasrat.adamo@gmail.com, ^nadhir.alansari@ltu.se,f.khajeek@ukh.edu.krd,varoujan49@yahoo.com
}

How to cite this paper: Adamo, N., AlAnsari, N. and Sissakian, V. (2021) Review of Climate Change Impacts on Human Environment: Past, Present and Future Projections. Engineering, 13, 605-630. https://doi.org/10.4236/eng.2021.1311044

Received: October 2, 2021

Accepted: November 27, 2021

Published: November 30, 2021

Copyright $\odot 2021$ by author(s) and Scientific Research Publishing Inc. This work is licensed under the Creative Commons Attribution International License (CC BY 4.0).

http://creativecommons.org/licenses/by/4.0/ (c) (i) Open Access

\begin{abstract}
Climate changes are one of the most significant aspects, which cause a threat to all human beings living on the planet Earth. Climate changes could happen due to both natural internal processes and external forcing, or due to persistent anthropogenic changes. The identified drastic temperature changes, increase in the emitted greenhouse gasses, and sea-level changes as witnessed from the acquired data; such as from ice cores, during the past centuries and even decades are all due to climate changes. Due to the increase in the emitted greenhouse gasses, major sectors in the Earth will be hit severely, such as agriculture and industry. Human welfare and health services will consequently suffer and development, in general, is going to be hampered. Large parts of the Earth will be unfavorable for living due to different reasons; such as inundation by seawater, decrease in temperature; however, some scientists believe that the increase in the percentages of the emitted greenhouse gasses has decreased or delayed the possibility of starting a new ice age. We have presented all possible scenarios, which may happen due to climate changes including temperature changes, emitted greenhouse gasses, sea level, and other harsh effects not only on human beings but all other living animal and plant species.
\end{abstract}

\section{Keywords}

Climate Change, Environment, Anthropogenic Changes, Greenhouse Gases, Sea Level Change

\section{Introduction}

Climate Change is not a new phenomenon in the history of Earth. The same 
history presents the consequent impacts and the full record of climate changes not only on the surface of the earth itself but on the existence and development of all beings living on it, be it humans, animals, or plants. Alternating ice ages had caused the extinction of kinds and species in the animal kingdom, and restricted the growth of plants in wide regions, while warm periods, however, had helped other kinds to grow and flourish. The same had governed the life of the human race, its geographical spread, and its ways of living. Favorable climate changes have contributed to the rise of civilization to the level of progress we know of today, but reversals due to mismanagement of man himself can destroy this civilization. A brief presentation of the history of climate changes may therefore help to grasp the root causes of these changes and assist in steering a safe course in mitigating the worst impacts that face humanity and the environment in the future. Needless to say, the sole responsibility of changes that we are witnessing rests almost all on Man himself.

\section{Climate Change Impacts during Early Age of the Earth}

Since the beginning of the Earth's history some 4540 million years ago [1], the world climate has varied on all timescales. It has swung between very warm conditions, with annual mean temperatures above $10^{\circ} \mathrm{C}$ in Polar Regions and glacial climates in which the ice sheets covered the majority of the mid-latitude continents. Scientists argue that such global climate change forcing had taken place at the early age of Earth resulting from continental shifts and great volcanic eruptions and more due to Earth orbital change. The timescale of global climate change forcing may be shown as in (Figure 1).

In Figure 1, for each of these climate changes forcing, an indicative range is shown. However, because of mutual interaction, they can exhibit variability on nearly all timescales. For instance, orbital forcing could influence the distribution of temperature and precipitation at the Earth's surface and then induce variations of the oceanic circulation and El Nino-Southern Oscillation-ENSO on multiple-millennial timescales, etc.

In more detail, these external forcing and processes can be described as follows:

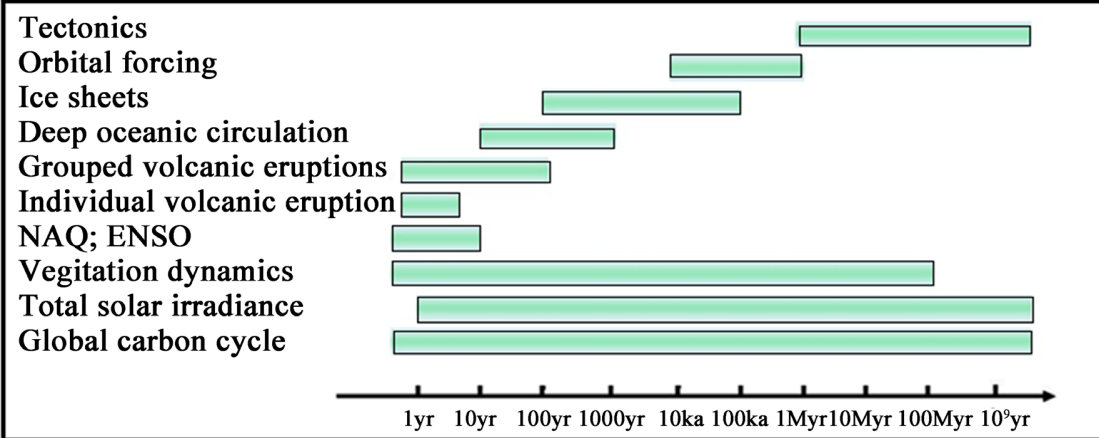

Figure 1. Schematic representation of the dominant timescales of some external forcing and processes related to internal dynamics that affect climate [2]. 
1) Earth Tectonics: The horizontal and vertical displacements associated with plate tectonics play a fundamental role in climate change over a wide range of timescales. The solid-earth surface is in direct contact with the atmosphere and oceans, and its evolving character affects the balance of incoming and outgoing radiation, atmospheric circulation, ocean currents, and the location of elevated terrain suitable for glaciers and ice sheets. Tectonic processes also have important indirect climatic effects through their control on geochemical cycling and the composition of the atmosphere and ocean [3].

2) Earth-orbiting Forcing: The low-frequency changes of the characteristics of the Earth orbit due to Earth tilting modify the amount of solar energy received in a particular season on every point on the Earth's surface, with the most important fluctuations located in the 10 to $100 \mathrm{ka}$ (kilo annum, Thousand-year) range (Figure 2) [4].

At the other end of the spectrum, lower amplitude fluctuations are also observed at interannual and decadal timescales, with no year being the same as a previous one.

3) Volcanic Eruptions: Individual volcanic eruptions produce general cooling during the years following the eruption. Furthermore, volcanic activity can be responsible for a low-frequency forcing if large eruptions are grouped in a particular decade or century. On longer timescales, increased volcanic activity related to plate tectonics can lead to strong cooling lasting thousands to millions of years [4].

4) The NAO and El Niño Oscillations: Moreover, internal dynamics also play a very important role in determining the variability of the Earth's climate. Global warming can also impact such internal dynamics as the El Niño Southern Oscillation (ENSO), the North Atlantic Oscillation (NAO), and the Southern Annular Mode (SAM), also known as the Antarctic Oscillation (AAO) which describes the north-south movement of the westerly wind belt that circles Antarctica [4].

5) Vegetable Dynamics: Scientists agree that seas and oceans were formed on the earth's surface some four billion years ago. Life, however, began about 3.5 billion years ago, which developed from single cells photosynthetic organisms. These began enriching the atmosphere with oxygen but Life remained mostly microscopic. Complex multicellular life arose, developed over time, at about 580

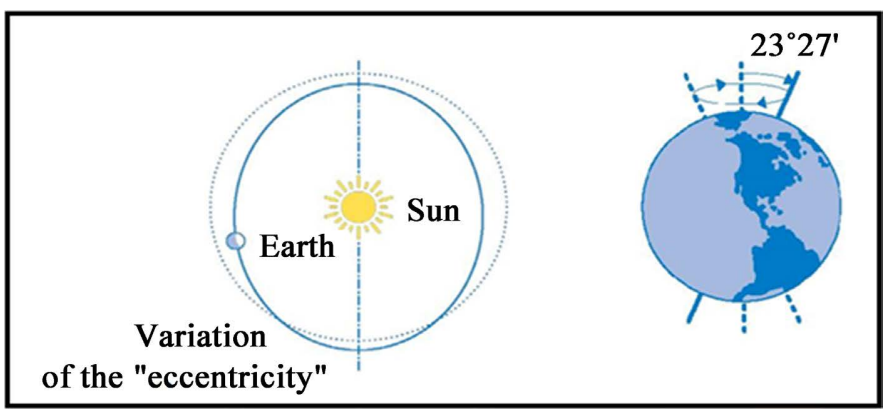

Figure 2. Schematic representation of the Changes in the eccentricity and the obliquity of earth orbit (source: Latsis foundation (2001)) [3]. 
million years, and culminated in the Cambrian Explosion about 541 million years ago [5].

At that time, practically all major groups started appearing in the fossil record and resulted in the divergence of most modern phyla (Figure 3).

This sudden boom and diversification of life forms produced most of the major species known today which has influenced the environment through the increase of Oxygen in addition to Carbon Dioxide emissions and other greenhouse gases. These acting together with other drives as shown already in (Figure 1) have changed the earth's environment throughout its long history, and, while climate change helped in the rise and development of millions of species of animals and vegetation's, it had contributed to the extinction of many millions of them also.

\section{The Ice Ages and Climate Change}

In the study of Climate Change, scientists have recorded five significant ice ages throughout the Earth's history: the Huronian (2.4 - 2.1 billion years ago), Cryogenian (850 - 635 million years ago), Andean-Saharan (460 - 430 mya), Karoo (360 - 260 mya) and Quaternary (2.6 mya-present). Approximately a dozen major glaciations have occurred over the past one million years, the largest of which peaked 650,000 years ago and lasted for 50,000 years. The most recent glaciation period, often known simply as the "Ice Age," reached peak conditions some 18,000 years ago before giving way to the interglacial Holocene epoch 11,700 years ago [7] (Figure 4).

For the last 500,000 years, the last glacial periods are marked with snowflakes (Figure 5). The most recent glaciation, which peaked at around $20 \mathrm{ka}$, is known

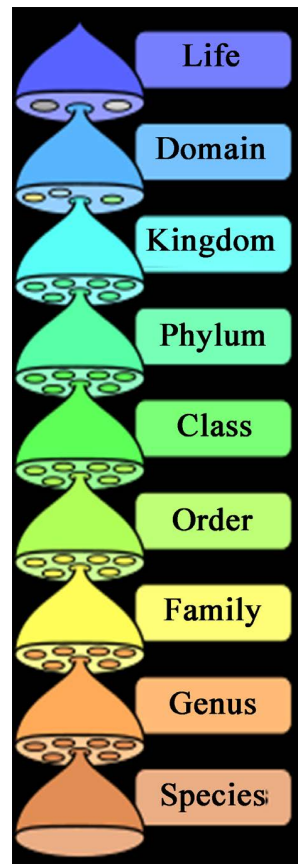

Figure 3. The hierarchy of biological classification's eight major taxonomic ranks [6]. 
as the Wisconsinan Glaciation. This figure describes the nature of the temperature change that followed each of these glacial periods [9] [10].

The current interglacial period (Holocene) is marked with an $(\mathrm{H})$ Point out of the previous five interglacial periods, (Figure 5) [11].

The "Holocene", the current geological epoch in which we live now, is thought to be the longest warm and "stable" climatic period of the last 400,000 years. This may have played a significant role in facilitating the development of human civilization. Being so it encompasses the appearance of the advent of agriculture and the birth and spread of civilizations during our human history some $9000-$ 10,000 years BC.

In supporting evidence of this development, the geological findings from Greenland Ice core dating using stable isotope measurements of oxygen isotope

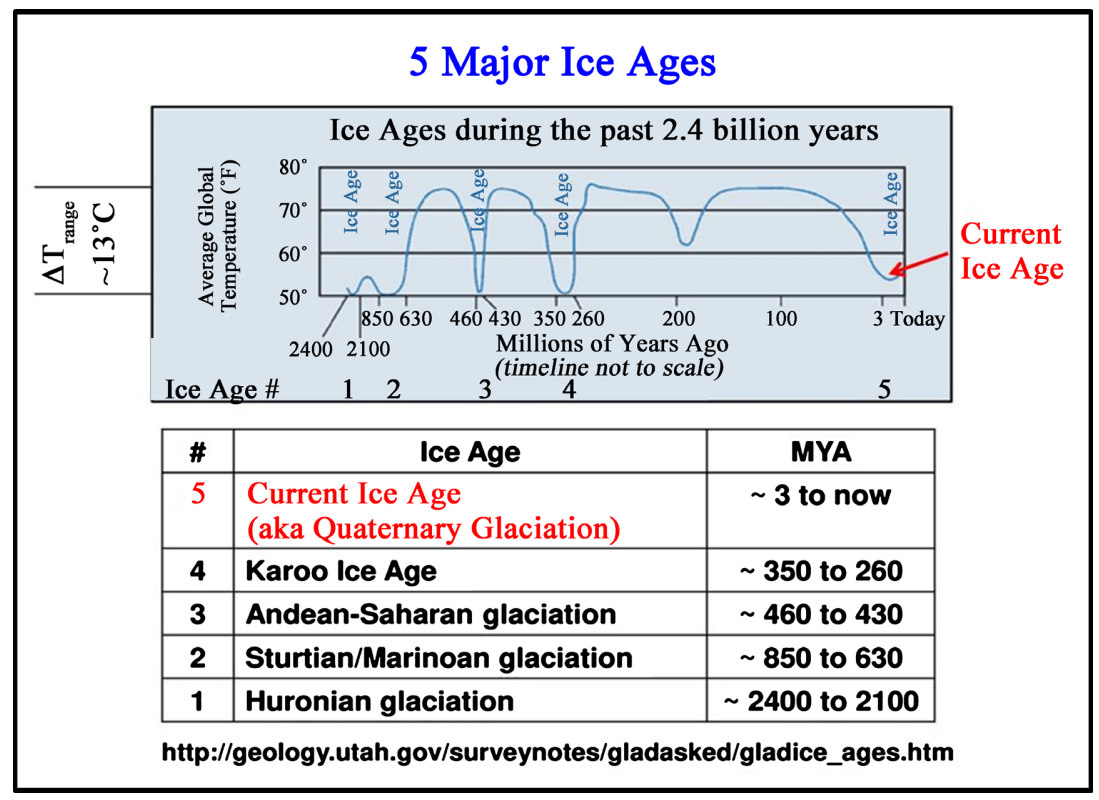

Figure 4. The five Major Ice Ages in the History of Earth. Modified from ref. [8].

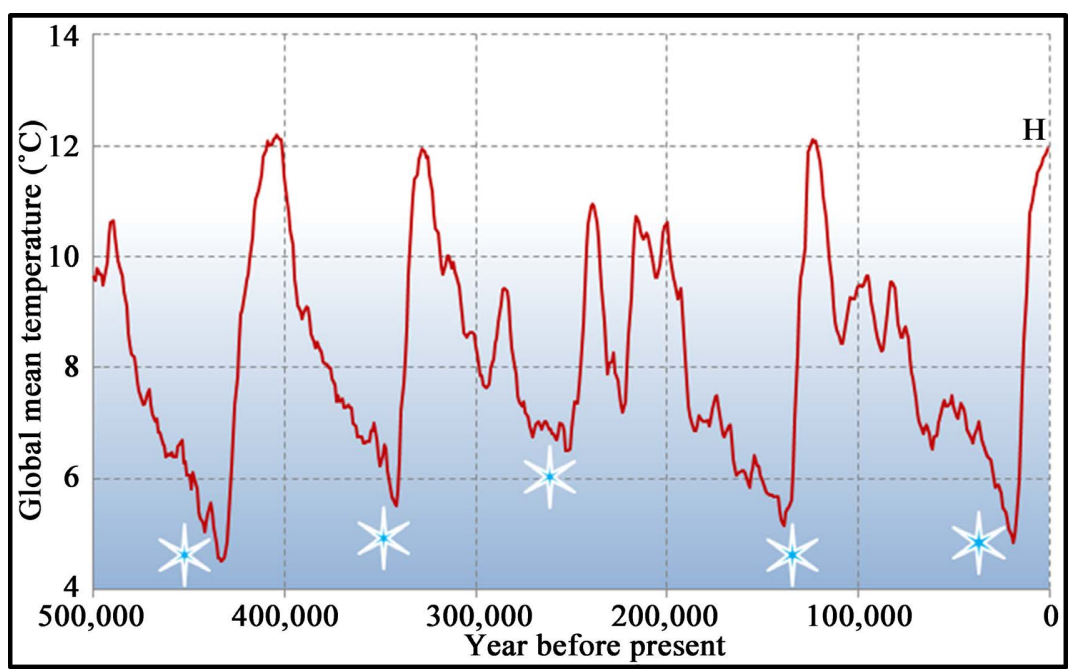

Figure 5. Global mean temperatures over the last 500,000 years [11]. 
$(\delta 18 \mathrm{O})$ indicates that the last ice age ended about $11,000 \mathrm{BC}$ and suggests that the extremely cold period ended about 9000 BC (Figure 6) [12].

In summary, it may be said that;

1) Throughout Earth's existence, the planet had been subjected to periods of cooling and warming that drastically altered the environment and the shapes of the continents and seas and all creatures that lived there.

2) It is also concluded that climate and ecology are very much related.

3) Even if it is difficult to estimate the rate at which changes had occurred, it is still possible to reconstruct atmospheric climates of the ancient past and how they changed the environment over time by using ice and ocean sediments cores.

4) It is important to note, however, that these changes had taken place over millions of years. Glacial and interglacial cycles had been caused by a combination of factors such as:

- The Milankovitch Cycle, which is the cyclical movement related to the Earth's orbit around the Sun;

- Change of $\mathrm{CO}_{2}$ concentrations in the atmosphere; and

- Water vapor presence and patterns [13].

\section{Climate Change Impacts after the Industrial Revolution}

An undisputed fact, which the scientific community has agreed upon today, is

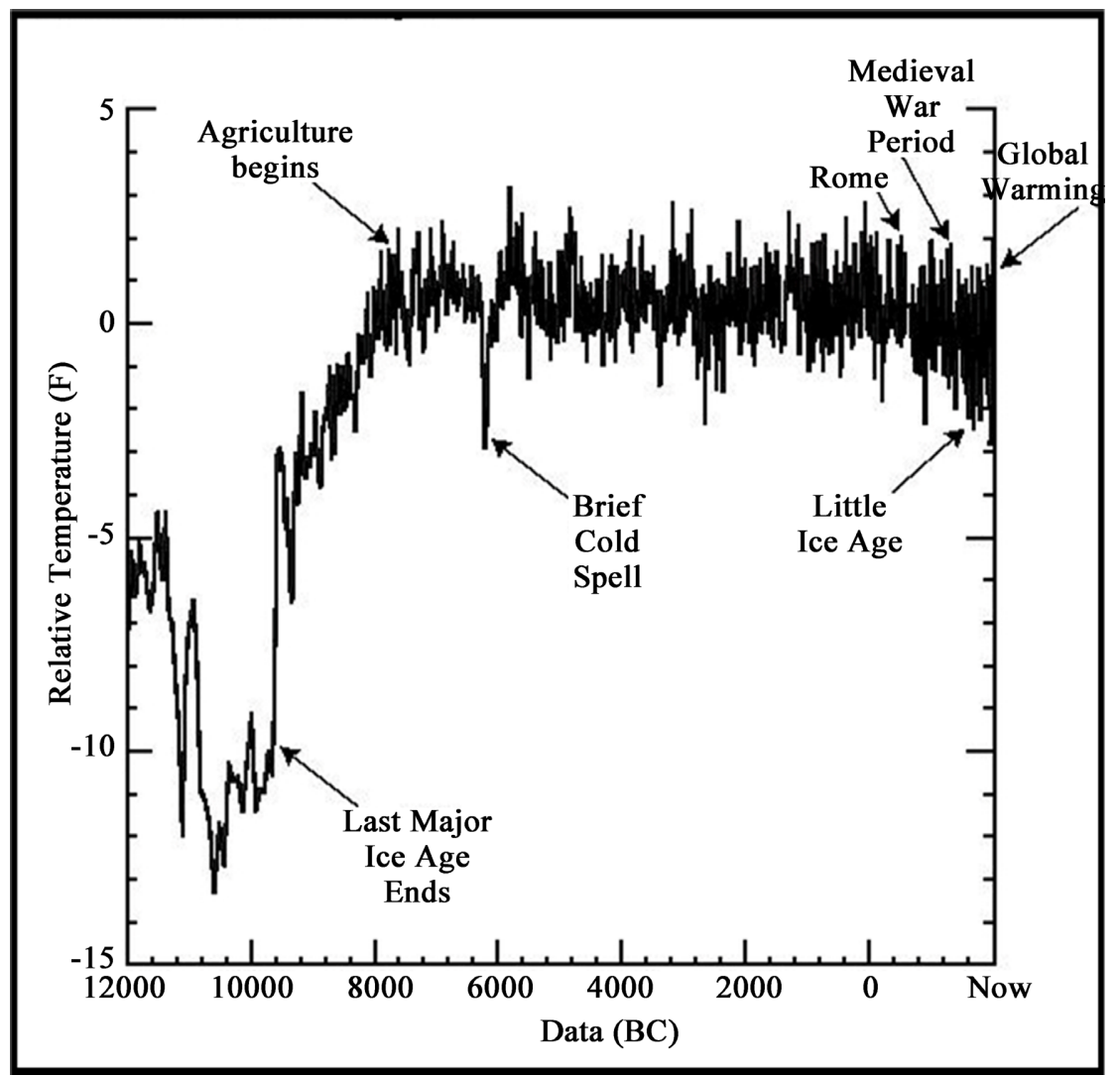

Figure 6. Temperature from 12,000 (BC) to the present from Greenland ice measurements of Oxygen isotopes [12]. 
the increased burning of fossil fuel since the beginning of the industrial revolution has resulted in the profound results of climate change, which we witness at the present.

In the early days of the Industrial Revolution, no one would have thought that the burning of fossil fuels would have an almost immediate effect on the climate. The impacts of such increase began to be felt, however, in some regions of the world as early as the $1830 \mathrm{~s}$. Scientific findings show that warming did not develop at the same time across the whole planet. The tropical oceans and the Arctic were the first regions to begin warming in the $1830 \mathrm{~s}$. Europe, North America, and Asia followed roughly two decades later.

This warming in most regions reversed what would otherwise have been a cooling trend related to high volcanic activity during the preceding centuries. From all available evidence, we can conclude that this warming is due to the carbon dioxide released into the atmosphere by humans. Such a conclusion is based on a comparison with records that extend back 500 years. These records were not derived from thermometers or satellites, but rather from natural climate archives which include coral skeletons, ice cores, tree rings, cave deposits, and ocean and lake sediment layers; all of which record the climate as they have grown or accumulated [14].

Since the beginning of the Industrial Revolution, humans have expelled considerable amounts of carbon dioxide into the atmosphere. This has triggered unnatural warming that has seen the Earth's temperature rise dramatically over a short period. The average global temperature was $12^{\circ} \mathrm{C}$ during the Last Glacial Maximum. During the following interglacial period, the average global temperature slowly rose to $13.8^{\circ} \mathrm{C}$. From 1880 to 2015 , it has increased by another $0.6^{\circ}$ degree to $14.4^{\circ} \mathrm{C}$. This rate of warming is about 50 times faster than the rate of warming during the previous 21,000 years. From 1950 to 2000 and beyond, carbon has increased in the atmosphere is a far steeper, more exponential curve (Figure 7), [15] [16] [17].

The Industrial Revolution began in the late eighteenth and early nineteenth centuries in Great Britain when the expansion of industry led to tapping new

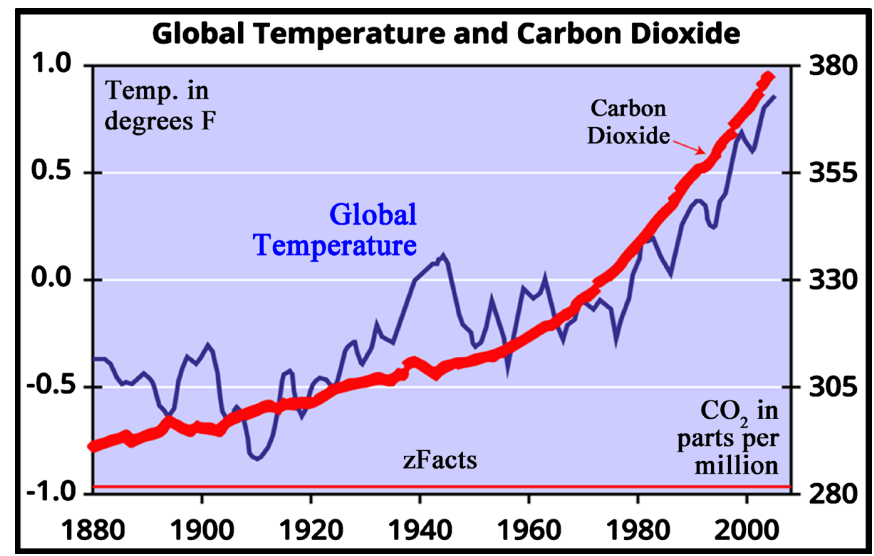

Figure 7. Global temperature rise vs. carbon dioxide emission since 1880 up to now [17]. 
sources of energy rather than relying on wood and waterpower. Around 1850, steam power was invented as a way to use coal energy more efficiently, and soon steam engines were used to power trains, ships, and industrial machinery of all sorts. These inventions spread soon throughout Europe, the United States, bringing enormous changes in society and commerce. Later in the nineteenth century, scientists learned how to generate electricity, and the discovery of oil led to the invention of the internal combustion engine; both technological developments that further changed the way humans lived and worked around the globe.

In 1896, the Swedish scientist Svante Arrhenius was the first to suggest that the burning of fossil fuels adds carbon dioxide gas to the Earth's atmosphere creating the greenhouse effect, which could raise the planet's average temperature. Arrhenius's discovery was dismissed by scientists who had reasoned that major climate change would not likely be produced by humans and could only happen slowly over tens of thousands of years. Most scientists at the time also believed that the vast oceans would absorb most of the carbon dioxide produced by industry.

By the $1950 \mathrm{~s}$ and $1960 \mathrm{~s}$, however, improved instruments for measuring longwave radiation allowed scientists to prove that Arrhenius's theory was correct. At that time, studies also confirmed that carbon dioxide levels were indeed rising year after year. In 1958, Charles D. Keeling, a scientist with the Scripps Institute of Oceanography in California, conducted the first reliable measurements of atmospheric carbon dioxide at Hawaii's Mauna Loa Observatory and found concentrations of the gas to be $315 \mathrm{ppm}$ and growing still [18].

Over the $18^{\text {th }}$ century, global $\mathrm{CO}_{2}$ emissions were a fraction of current levels. During the $18^{\text {th }}$ Century and early $19^{\text {th }}$ century, global $\mathrm{CO}_{2}$ emissions were around 3 to 7 million tons per year. During the early $19^{\text {th }}$ Century, $\mathrm{CO}_{2}$ emissions steadily rose reaching 54 million tons per year by 1950 . Currently, we are emitting over 8000 million tons per year, (Figure 8) [19].

The increase of $\mathrm{Co}_{2}$ concentration in the atmosphere, which has resulted from the increase of fossil fuel and causing global warming, is not the only reason for this warming. Data for the past 2000 years show that the atmospheric concentrations of $\mathrm{CO}_{2}, \mathrm{CH}_{4}$, and $\mathrm{N}_{2} \mathrm{O}$; the three important greenhouse gases, have increased substantially since about 1750 . Rates of increase in levels of these gases are dramatic. $\mathrm{CO}_{2}$, for instance, never increased more than $30 \mathrm{ppm}$ during any previous 1000-year period in this record, but it has already risen by $30 \mathrm{ppm}$ in the past two decades, (Figure 9) [20].

Some scientists claim that the present global warming resulting from the increase in greenhouse gases emissions is not very bad or maybe even advantageous, and it looks like these emissions are preventing the onset of a new ice age. Based on previous cycles, the Earth is probably due to going into an ice age about now. Conditions were starting to line up for a new ice age at least 6000 years ago. Before the Industrial Revolution, summers were getting colder in the northern hemisphere, but that trend has now been comprehensively reversed 


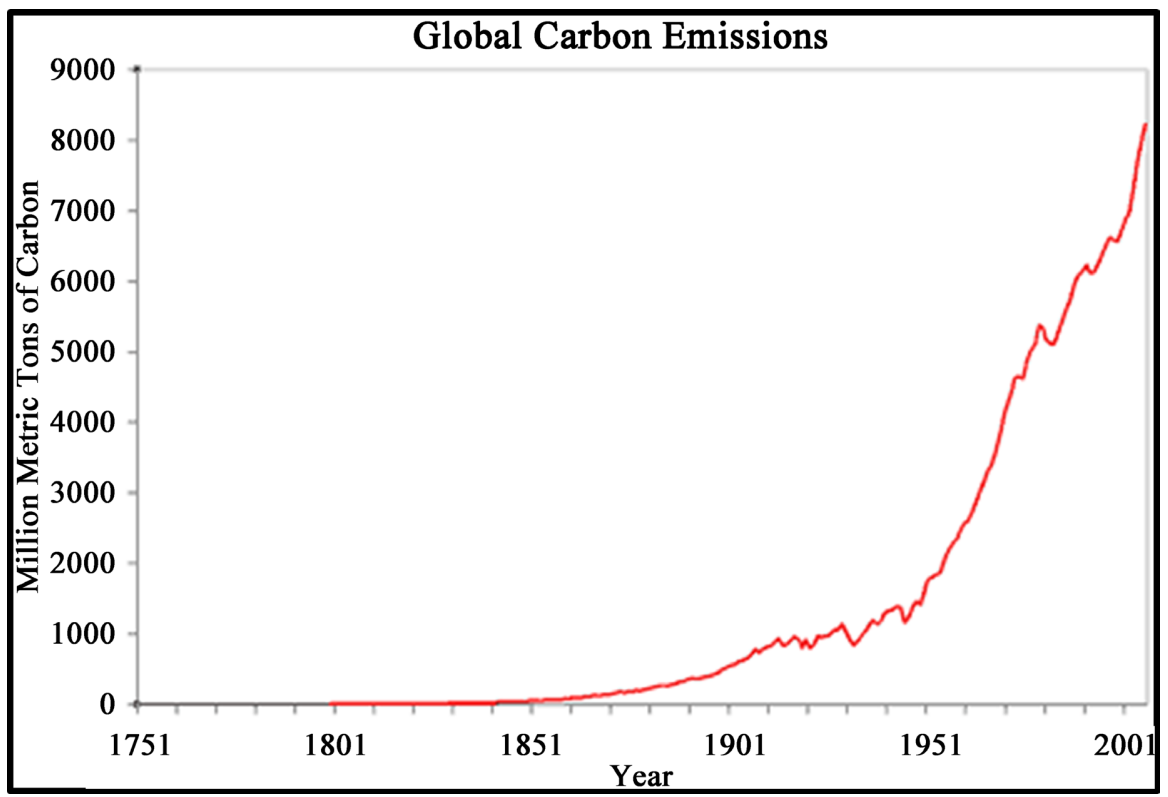

Figure 8. Emission of $\mathrm{Co}_{2}$ during the $18^{\text {th }}$ and its increase up to 2001 (Last updated on 9 July 2010 by John Cook) [19].

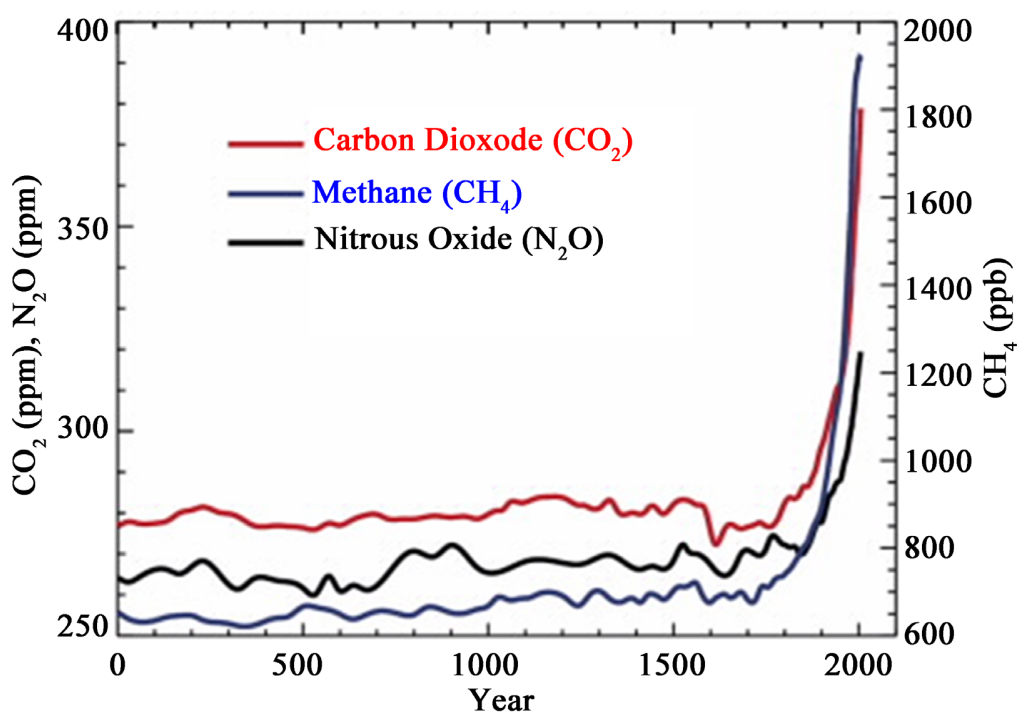

Figure 9. Increase of the most important greenhouse gases for the last 2000 year [20].

because of the increasing greenhouse gases in the atmosphere of the earth. One hypothesis claims that it is not just industrial society, which is responsible for these emissions, but this had started ever since humans began practicing largescale farming, at least 5000 years ago, with the greater emission of methane from rice paddies.

Therefore, not just greenhouse gas emissions over the last 200 years may have stopped us from going into a new ice age, but it is greenhouse gas emissions for the last 5000 years that have collectively helped to steer us away from the next ice age. By this, we may have delayed the onset of the next ice age for now, but if another one starts now, it will have big consequences for human 
civilization. Besides the fact it would be awfully a lot colder, huge regions where hundreds of millions of people live would become uninhabitable. They would be covered in thick ice sheets and subject to an inhospitable climate. Assuming it was similar to the last ice age, then North America would be covered in ice, the whole of northern Europe, the whole of northern Asia would be covered in ice too.

The full impacts of a new ice age may be summarized as follows;

1) There would be a lot less agricultural land available, so it would be very difficult to support the human population.

2) The physical shape of the continents would look completely different across the whole planet due to the receding coastlines of the shrinking seas and oceans.

3) A huge drop in sea level of up to 120 meters would close down marine channels; the Mediterranean Sea, Torres Strait, Bass Strait, and Bering Strait, and create new areas of land that could be used for habitation or agriculture.

4) Ocean ports would no longer be on the ocean, and anyone wanting water views would need to relocate large distances [21].

\section{Understanding Current Climate Changes and Future Trends}

The present situation of climate change and its impacts on the environment is a subject nowadays of a heated debate and feverish scientific research on all the current and future projections of these impacts. The focus is global warming, which has become so much noticeable everywhere in the world today as a result of increasing anthropogenic activities. Much scientific studies and research have been conducted to define and quantify the factors contributing to this warming and its contribution to disasters and deep environmental changes occurring now and those expected in the future. Climate change can cause significant impacts on water resources and the hydrological cycle resulting in things like; fast melting of the North and South Pole's snow packs' due to land temperature rise, the associated sea level rising, changes of the precipitation patterns over almost all parts of the world. Other changes to specific regions, which fall within the framework of these changes and have become daily news on the media are, unprecedented floods, violent tornados, recurrent hurricanes, severe droughts, and loss of crops, in addition to unprecedented sandstorms and increase of desertification. Major sectors will be hit severely, such as agriculture and industry. Human welfare and health services will consequently suffer and development, in general, is going to be hampered.

This situation has led international governmental bodies such as the Intergovernmental Panel for Climate Change (IPCC), established in 1988, and the UN World Meteorological Organization (WMO), to have a keen interest in studying the factors behind this phenomenon.

The (IPCC) issued its first report on these changes in 1990 under the title

"Climate Change 1995-The Science of Climate Change", in which it defines the 
principles governing this change and its foundation [22]. According to this report, climate change could happen due to both natural internal processes and external forcing, or due to persistent anthropogenic changes. It does not rule out the possibility that the rise in temperature from 1850 to 1950 was a natural phenomenon, perhaps due to changes in the Sun; but the subsequent warming from 1957 until now, however, is different and is attributed to human actions.

According to NOAA's 2020 Annual Climate Report, the combined land and ocean temperature has increased at an average rate of 0.13 degrees Fahrenheit (0.08 degrees Celsius) per decade since 1880; however, the average rate of increase since $1981\left(0.18^{\circ} \mathrm{C} / 0.32^{\circ} \mathrm{F}\right)$ has been more than twice that rat [23].

World Meteorological Organization (WHO) considers that climate change refers to "a statistically significant variation in either the mean state of the climate or in its variability which is persisting for an extended period (typically decades or longer)", and it adds; "Climate change may be due to natural internal processes or external factors such as persistent changes to the atmosphere or changes in land use" [24].

The United Nation Framework Convention on Climate change (UNFCC 1992), however, is more specific on this where it defines climate change as: "a change of climate which is attributed directly or indirectly to human activity that alters the composition of the global atmosphere and changes the natural climate variability observed over comparable periods" [25].

The (IPCC) has qualified "Change" by asserting that, "It is the change which may occur over this century as a result of human activates in the composition of the atmosphere or land use [26]. The (IPCC) stipulates that this warming is very likely caused, at least in part, by human activity and that most of the observed warming over the last 50 years is due to the increase in greenhouse gas concentration, and adds that discernible human influences extend now to other aspects of climate change, including ocean warming, continental-average temperatures rise, temperature extremes and the changes in wind circulation [27].

In tracing the reasons for this temperature rise, scientific evidence attributes it to increased use of fossil fuel leading to increased release of carbon dioxide $\left(\mathrm{CO}_{2}\right)$. Research has shown that the concentration of $\mathrm{CO}_{2}$ has increased from a relatively constant level of $280 \mathrm{ppm}$ where it had been during the period from AD800 - AD1800 to the value of $380 \mathrm{ppm}$ in the last decade of the $20^{\text {th }}$ century; an increase of $36 \%$. Summing up the proceedings, it may be said that: The warming phenomenon, which is generally called the greenhouse effect, is, therefore, attributed to the increase of the concentration of $\mathrm{CO}_{2}$ and the other Greenhous Gases (GHG) in the atmosphere resulting from increased human activities. The greenhouse gases, in addition to Carbon Dioxide $\left(\mathrm{CO}_{2}\right)$, are Methane $\left(\mathrm{CH}_{4}\right)$, nitrous oxide $\left(\mathrm{N}_{2} \mathrm{O}\right)$, and fluorinated gases, as already explained.

One example of the magnitude of the (GHG) emissions may be seen in the case of the USA. An overview of these emissions in the USA during 2019 is shown in (Figure 10). 


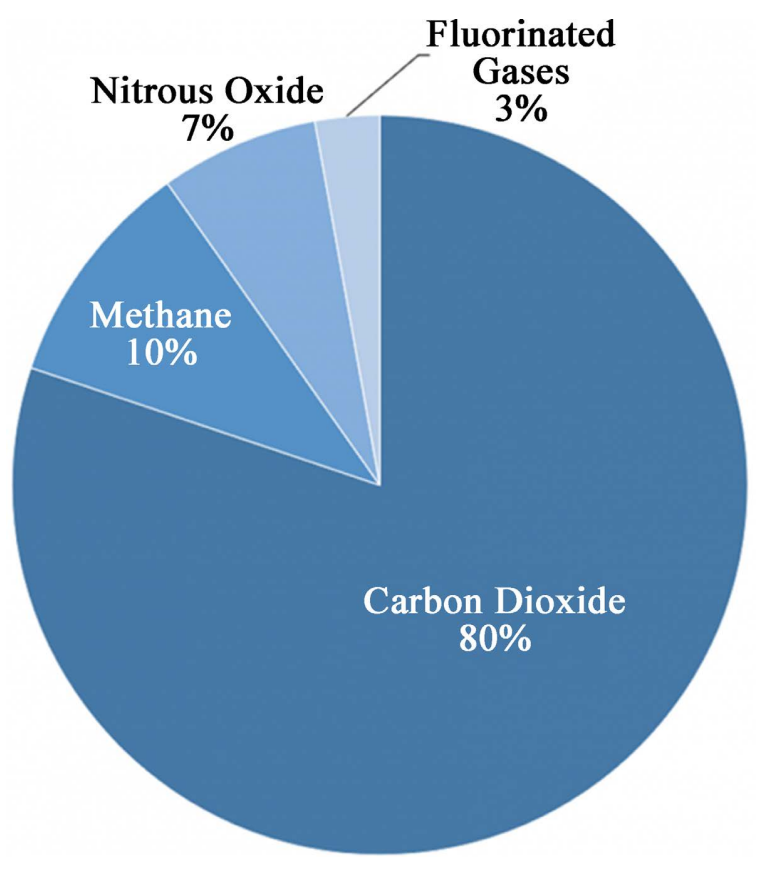

Figure 10. Overview of U.S Greenhouse Gas Emissions in 2019 [28].

\section{Scenarios of Future Climate Changes}

A major advance in the assessment of climate change projections was presented in IPCC's (2007) fourth assessment report compared with its third assessment report (2001). In this report, a large number of simulations were available from a broader range of models. Taken together with additional information from observations, these provide a quantitative basis for estimating likelihoods for many aspects of future climate change. Model simulations cover a range of possible futures idealized emissions or concentration assumptions and include illustrative marker scenarios for the 2000 to 2100 period and model experiments with greenhouse gases and aerosol concentrations held constant after the year 2000 or 2100. If the emission of these gases continues at the present trend, in the absence of any action to limit this emission, then the projections of the temperature rise at the end of the $21^{\text {st }}$ century will range from $1.1^{\circ} \mathrm{C}$ to $6.4^{\circ} \mathrm{C}$, compared to the end of the $20^{\text {th }}$ century [29].

For the projected patterns of climate change, the IPCC defined six emission scenarios from 2000 to 2100 in the absence of additional climatic policies. These Scenarios are shown in (Figure 11). This figure indicates that the degree of severity of these scenarios increases from Scenario (B1) to Scenario (A1F1), [30].

The six IPCC scenarios for GHG emission are described in brief as follows:

The A1 scenarios are of a more integrated world. The (A1) family of scenarios is characterized by: Rapid economic growth, a global population that reaches 9 billion in 2050 and then gradually declines, the quick spread of new and efficient technologies, a convergent world income and way of life converge between regions, extensive social and cultural interactions worldwide. There are subsets to the (A1) family based on their technological emphasis: (A1FI), in which an 


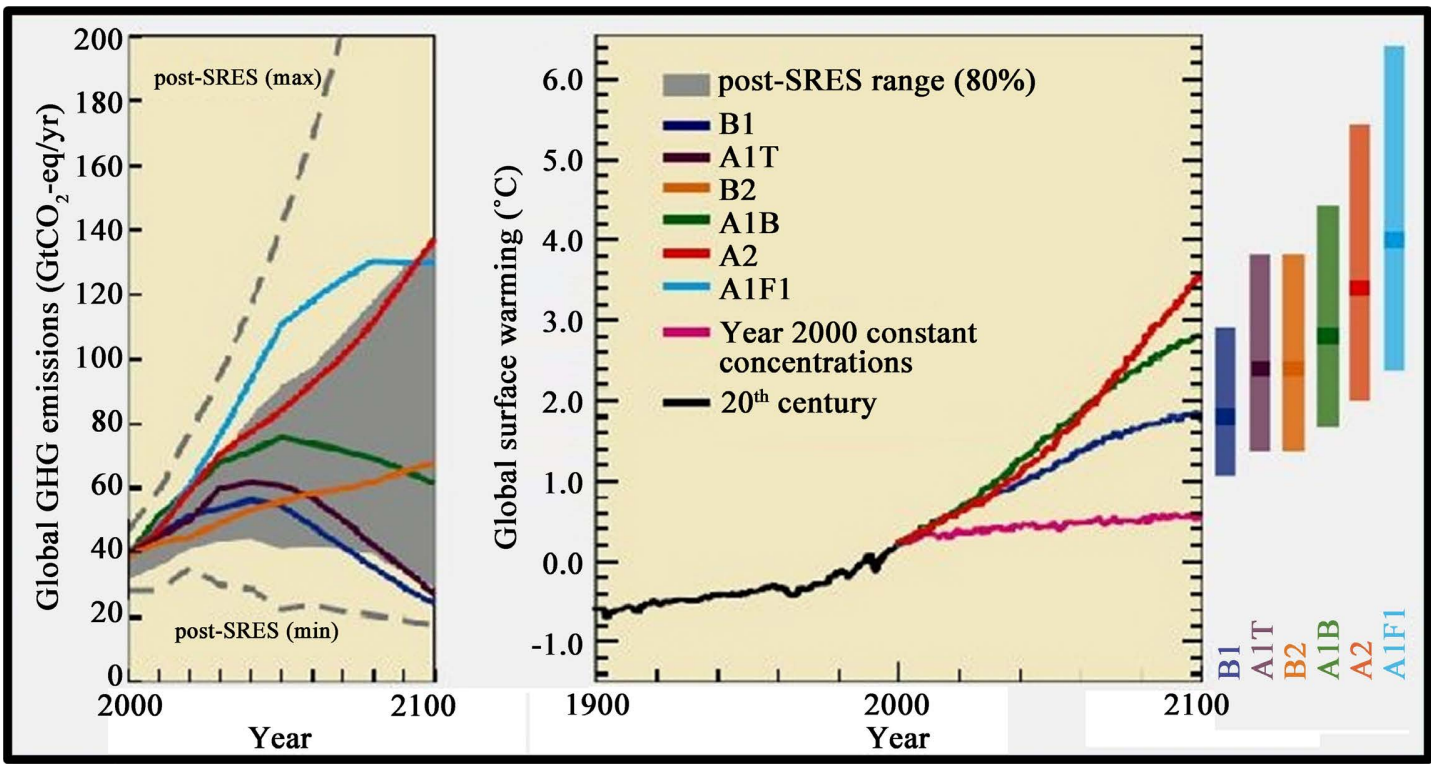

Figure 11. Scenarios for GHG emission from 2000 to 2100 in the absence of additional climate policies, and projections of surface Temperature [30].

emphasis on fossil-fuels (Fossil Intensive), (A1B) characterized by a balanced emphasis on all energy sources, (A1T) on which emphasis is put on non-fossil energy sources.

The A2 scenarios are of a more divided world. The (A2) family of scenarios is characterized by: A world of independently operating, self-reliant nations, continuously increasing population, regionally oriented economic development.

The B1 scenarios are of a more integrated world, and more ecologically friendly. The (B1) family of scenarios is characterized by: Rapid economic growth as in (A1), but with rapid changes towards a service and information economy, Population rising to 9 billion in 2050 and then declining as in (A1), reductions in material intensity and the introduction of clean and resource-efficient technologies, an emphasis on global solutions to economic, social and environmental stability.

The B2 scenarios are of a more divided world, but more ecologically friendly. The (B2) scenarios are characterized by: continuously increasing population, but at a slower rate than in (A2). Emphasis on local rather than global solutions to economic, social, and environmental stability, Intermediate levels of economic development, less rapid and more fragmented technological change than in (A1) and (B1).

In predicting future climate change impacts on any region in the world, modeling studies are normally performed to forecast these changes to such a future time as the end of the $21^{\text {st }}$ Century. Such studies may use one or more of the above-mentioned IPCC-defined emission scenarios as input and utilizes one of the General Circulation Models (GCMs) [31]. Other modeling procedures may even utilize some kind of hydrologic models such as the Max Plank Institute Hydrological model [32], or one of the Regional Climate Models for climate ap- 
plication (RCMs) [33] [34].

\section{Expected Future Impacts on the Environment}

Since IPCC's third assessment Report (TAR-The Scientific Basis) was issued in 2001, it was followed by more studies and reports. The most likely future impacts to be expected until the end of the 21st century were outlined by the IPCC 2007 report [35]. Many more studies were also carried out all over the world to outline such expected impacts.

In summary, the conclusions of these reports and studies may be listed below:

1) For the next two decades following 2007 , a warming of about $0.2^{\circ} \mathrm{C}$ per decade is projected for a range of emission scenarios. Even if the concentrations of all greenhouse gases and aerosols are kept constant at 2000 levels, further warming of about $0.1^{\circ} \mathrm{C}$ per decade will occur. Continued greenhouse gases emissions at or above 2007 rates would cause further warming and induce many changes in the global climate system during the $21^{\text {st }}$ century.

2) Snow cover is projected to contract. Widespread increases in thaw depth are projected over most permafrost regions.

3) Heat extremes, heat waves, and heavy precipitation events will likely continue to become more frequent.

4) Based on a range of models, it is likely that future tropical cyclones (typhoons and hurricanes) will become more intense, with larger peak wind speeds and more heavy precipitation associated with ongoing increases of tropical sea surface temperatures.

5) Extratropical storm tracks are projected to move poleward, with consequent changes in wind, precipitation, and temperature patterns, continuing the broad pattern of observed trends over the last half-century.

6) For the projected warming in the $21^{\text {st }}$ century according to scenarios (B1, A1B, A2), the geographical distribution is similar to those observed over the past several decades. Warming is expected to be greatest over land and at most high northern latitudes, and least over the Southern Ocean and parts of the North Atlantic Ocean (Figure 12) [36].

Projected surface temperature changes for the early and late 21 st century relative to the period 1980-1999.

7) Increases for precipitation are very likely in high latitudes, while decreases are likely in most subtropical land regions by as much as about $20 \%$ in the A1B scenario in 2100 continuing observed patterns in recent trends (Figure 13).

\section{Projected Patterns of Precipitation Changes}

Changes predicted by the SRES A1B scenario, for the period 2080 to 2099 relative to 1980 to 1999, for Multi-model mean in surface air temperature, precipitation, and sea level pressure for boreal winter DJF and summer JJA are likely to be as shown in (Figure 14).

8) On regional scale climate change may have strong influence on the precipitation and temperatures over many regions of the world. One of such regions is 


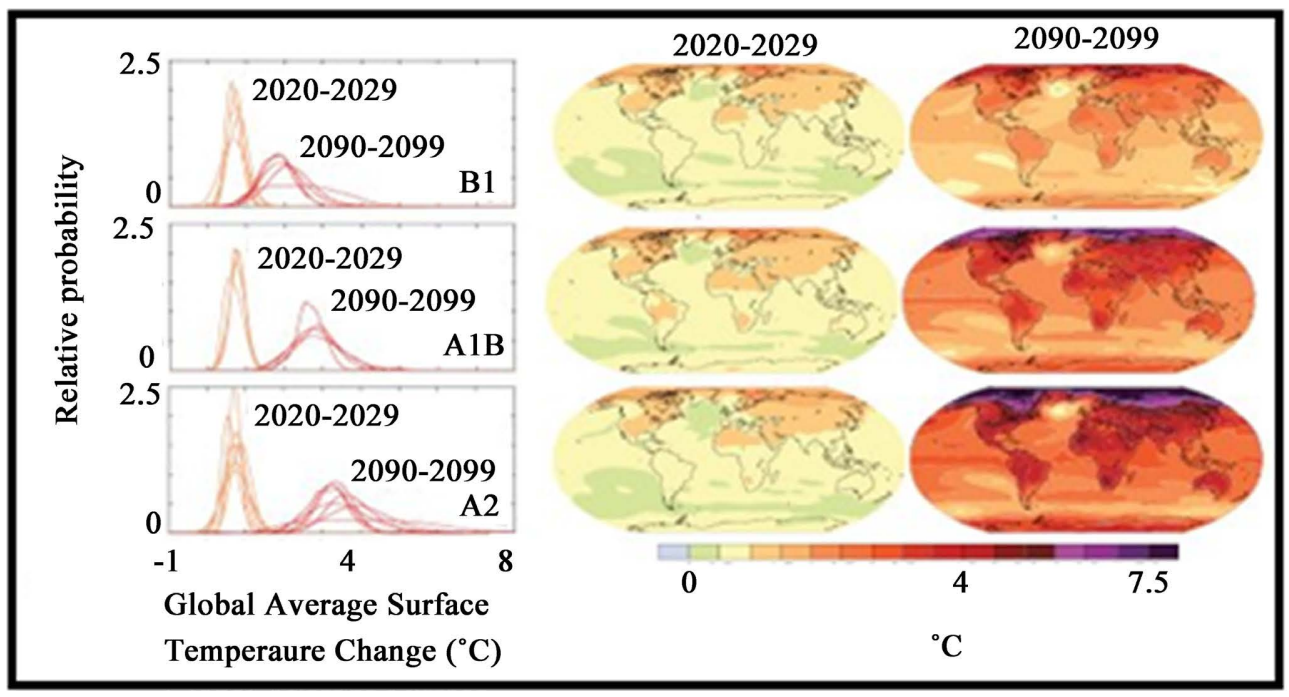

Figure 12. SPM.6. Projected surface temperature changes for the early and late $21^{\text {st }}$ century relative to the period 1980-1999. The central and right panels show the AOGCM multi-model average projections for the B1 (top), A1B (middle) and A2 (bottom) SRES scenarios averaged over the decades 2020-2029 (center) and 2090-2099 (right). The left panels show corresponding uncertainties as the relative probabilities of estimated global average warming from several different models [36].

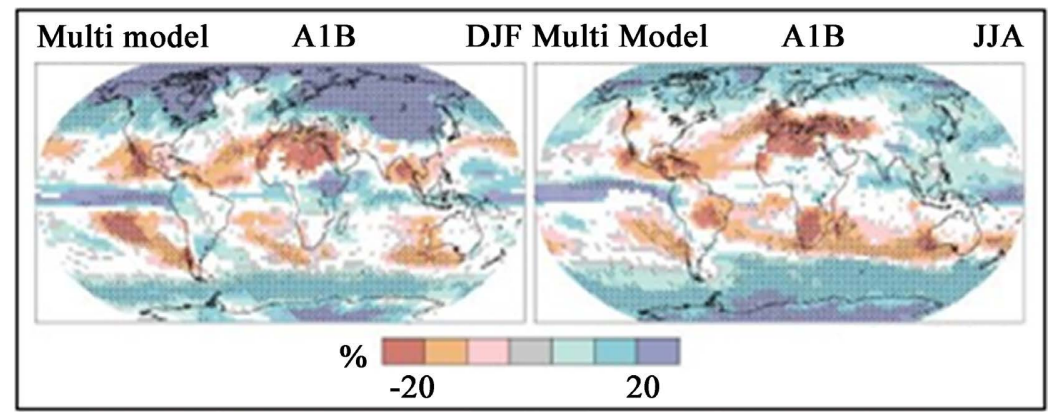

Figure 13. Relative changes in precipitation (in percent) for the period 2090-2099, relative to 1980-1999. Values are multi-model averages based on the SRES A1B scenario for December to February (left) and June to August (right). White areas are where less than $66 \%$ of the models agree in the sign of the change and stippled areas are where more than $90 \%$ of the models agree in the sign of the change [37].

the Himalayas, where impacts will be felt in the melting response of glaciers or snow cover and, in turn, affects the runoff pattern of rivers draining from the glaciated catchments. Three major river catchments along with their several tributaries originating from Indian as well as Nepal part of Himalayas receive a significant contribution from the Himalayan cryosphere, especially during the non-rainfall lean period of the year. This situation has promoted carrying out good amount of research work to predict the range of these impacts. Citing only one example of such research is, the modelling study using regional climate model PRECIS to obtain projection of future precipitation and temperature change over the transboundary Koshi River Basin. This study has shown that rainfall is expected to decrease in the coming years up to (2040), but then progressively increase towards the end of the $21^{\text {st }}$ century. Summer monsoons are 
expected to increase over the base period towards the 21 st century. Moreover, progressive increase in maximum and minimum temperature is projected for the future. All simulations indicated a significant rise in temperature (between $4^{\circ} \mathrm{C}-6^{\circ} \mathrm{C}$ ) throughout the basin, while analysis of extreme temperature indicates that maximum daily temperature may be more in the future [39].

9) Based on current model simulations, it is very likely that the meridional overturning circulation (MOC) known also as the "Thermohaline Circulation" is a system of surface and deep currents, encompassing all ocean basins will undergo some changes (Figure 15).

The MOC circulation often referred to as the ocean's "conveyor belt", links major surface and deep-water currents in the Atlantic, Indian, Pacific, and Southern Oceans. Multiple mechanisms conspire to increase the density of surface

Temperature A1B: 2080-2099 DJF

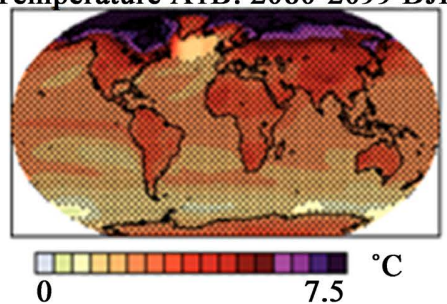

Temperature A1B: 2080-2099 JJA
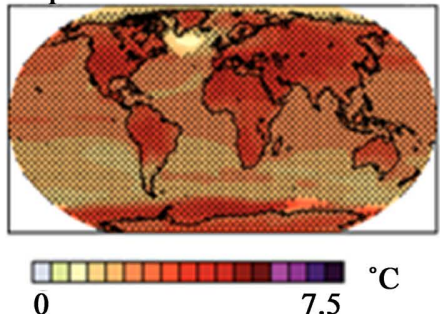
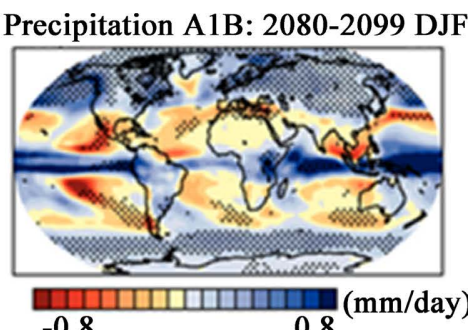

$$
-0.8
$$

0.8

Precipitation A1B: 2080-2099 JJA
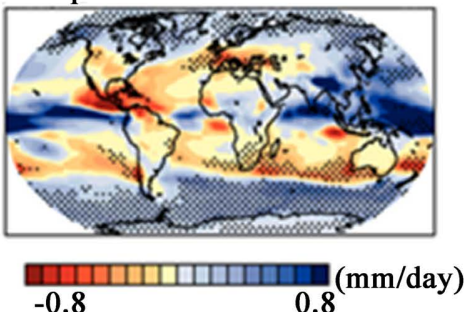

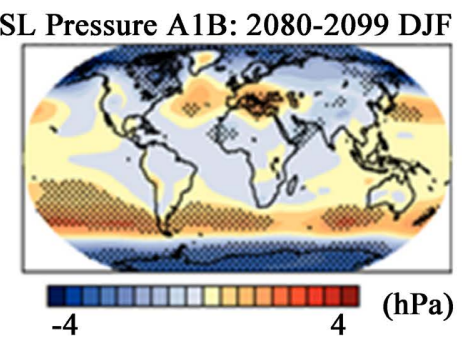

SL Pressure A1B: 2080-2099 JJA

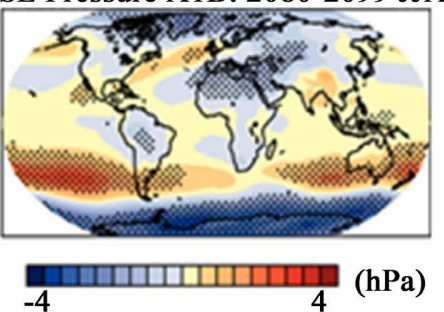

Figure 14. Multi-model mean changes in surface air temperature $\left({ }^{\circ} \mathrm{C}\right.$, left), precipitation $\left(\mathrm{mm} \cdot \mathrm{day}{ }^{-1}\right.$, middle) and sea level pressure ( $\mathrm{hPa}$, right) for boreal winter (DJF, top) and summer (JJA, bottom). Changes are given for the SRES A1B scenario, for the period 2080 to 2099 relative to 1980 to 1999. Stippling denotes areas where the magnitude of the multi-model ensemble mean exceeds the inter-model standard deviation [38].

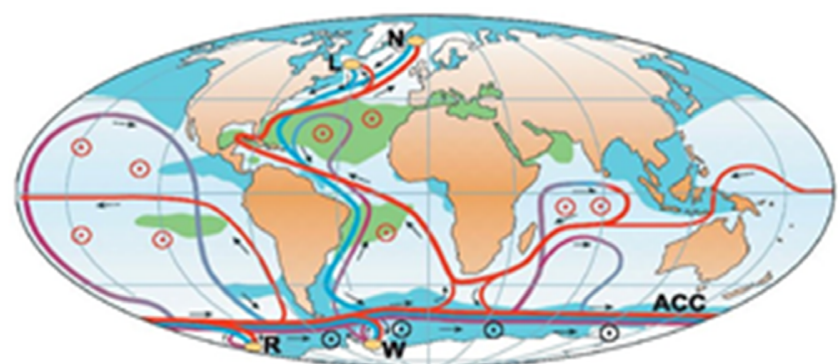

- Surface flow

- Deep flow

- Bottom flow

- Deep water formation
$\odot$ Wind-driving upwelling
L Labrador Sea
$\odot$ Mixing-driven upwelling
Salinity $36 \%$
= Salinity $34 \%$
N Nordic Seas
W Weddell Sea
R Ross Sea

Figure 15. Schematic of the Global Overturning Circulation. (ACC is the Antarctic Circumpolar Current) [39]. 
waters at high latitudes. Cold winds blowing over the oceans chill the waters beneath them. These winds also increase evaporation rates, further removing heat from the water. These chilled waters have increased densities, and thus tend to sink. The formation of sea ice also helps to increase the density of water near Earth's poles. As seawater freezes, salt is forced out of the ice in a process called "brine exclusion". The ice is essentially not salty. The excluded salt increases the salinity of the cold water immediately below the ice, making it denser still. The salty, cold water near the poles sinks toward the ocean floor [40] [41].

Those of the Atlantic Ocean will slow down during the $21^{\text {st }}$ century. The multi-model average reduction by 2100 is $25 \%$ (range from zero to about $50 \%$ ) for emission scenario (A1B). Temperatures in the Atlantic region are projected to increase despite such changes due to the much larger warming associated with projected increases in greenhouse gases. It is very unlikely that the MOC will undergo a large abrupt transition during the $21^{\text {st }}$ century. Longer-term changes in the MOC cannot be assessed with confidence [42].

10) Anthropogenic warming and sea-level rise would continue for centuries due to the time scales associated with climate processes and feedbacks, even if greenhouse gas concentrations were to be stabilized [43].

11) Global warming may drive a quarter of land animals and plants to the edge of extinction by 2050. In the worst-case scenario, between a third to a half of land animal and plant species will face extermination. The predictions come from extinction models based on over 1100 species covering a fifth of the Earth's landmass.

The bleak scenario results from a study conducted at the University of Leeds, UK (2004), which has evaluated the impact on species of mild, moderate, and severe levels of predicted climate change stipulates that; "In the absolute bestcase scenario, which is unrealistic, with the minimum expected climate change and all of the species moving completely into new areas which become suitable for them, an estimated nine percent will be facing extinction" [44].

12) The changing weather patterns and ocean temperatures affect agriculture, fish, wildlife, water, and energy. Crop yields are affected by temperature and water stress as well as the length of the growing season fall by $10 \%-25 \%$. They are less predictable as key regions shift from a warming to a cooling trend. As some agricultural pests die due to temperature changes, other species spread more readily due to the dryness and windiness-requiring alternative pesticides or treatment regiments. Commercial fishermen that typically have the right to fish in specific areas will be ill-equipped for the massive migration of their prey [45].

13) The carrying capacity of Earth and its natural ecosystems including social, economic, and cultural systems are limited, and they can support a finite number of people on the planet. Given the current climate changes, it is unclear where sufficient clean water supply will come from in many areas around the world where the population is exploding. Over centuries, we have learned how to produce more food, energy, and access more water. However, will the potential of new technologies be sufficient when a crisis like the one outlined in these 
climate changes scenarios hit? Abrupt climate change is likely to stretch carrying capacity well beyond its already precarious limits. In addition, there is a natural tendency or need for carrying capacity to become realigned. As abrupt climate change lowers the world's carrying capacity, aggressive wars are likely to be fought over food, water, and energy. Deaths from the war as well as starvation and disease will decrease population size, which over time, hopefully, will rebalance with carrying capacity [46].

14) Violence and disruption stemming from the stresses created by abrupt changes in the climate pose a different type of threat to national security than it is accustomed to today. A military confrontation may be triggered by a desperate need for natural resources such as energy, food, and water rather than by conflicts over ideology, religion, or national honor. The shifting motivation for confrontation would alter most vulnerable countries and the existing warning signs for security threats [47].

15) Climate change gives rise to environmental conditions that can have farreaching effects on human health and existence. Direct effects are diseases and deaths because of extreme weather events like heat, flooding, landslides, storms, and hurricanes. Indirect effects are those that result from changes in the ecosystem, such as conditions that facilitate infectious diseases, changes in agricultural production, and the availability of (clean) water. However, climate change can also have indirect effects on health from the social and economic turmoil brought on by drought, flooding, famine, epidemics, and the movement of refugees [45].

\section{Climate Change within the Tigris and Euphrates Area}

The Middle East area is highly vulnerable to climate change [48] and Tigris and Euphrates Rivers are located within this area. This area is categorized by a high degree of aridity, high variability, and very low annual rainfall [49] and can experience major environmental changes due to any climatic shift [50]. It is believed that climate change can have a significant effect on the environment and economy, particularly in the agricultural sector. The work executed on climate change and its effect on water resources indicates that water scarcity has become significantly worse [51] [52] [53] [54] [55].

Climate change has affected the agricultural sector [49] [55] which is the second-largest contributor to the country's gross domestic product in Iraq and forms the main source of livelihood for $25 \%$ of the population [56]. In addition, the water quality of the rivers deteriorated with the decrease in water availability [53]-[58].

High temperatures and very low rainfall levels are depriving millions of people of drinking and agricultural water [59]. Millions of people are suffering from losing access to water, food, and electricity in Syria and Iraq [60] [61] [62]. In addition, Turkey aims to take advantage of its abundance of water resources to achieve its strategic political and economic goals [63]. This gives a very negative 
impact on Syria and Iraq and will cause friction and conflict.

\section{Steps Taken So Far and Required Future Actions to Mitigate Climate Change Impacts}

Although the Swedish scientist Svante Arrhenius sounded warning on the increased concentration of $\mathrm{CO}_{2}$ in the atmosphere as a result of burning fossil fuel since 1896, this was not taken seriously until 1957 when Charles Keeling published his project work on measuring the concentration of carbon dioxide in the atmosphere. Figure 16 is a version of Keeling's curve updated 2020, which shows alarming results of the increased concentration. Results for 2021 are not available yet.

During the 1970s, onwards feverish research work supported by governments actions and by NGO environmental groups gathered full momentum to study, evaluate the magnitude of the problem and suggest future actions and solutions. In 1972 the first UN environment conference, which led to the formation of the United Nations Environment Program, was concluded. This, in turn, established the Intergovernmental Panel on Climate Change (IPCC) in 1988. The IPCC does not carry out its research, but rather it looks at the literature published elsewhere, relying upon the work of thousands of scientists over the world. Each IPCC report is a massive undertaking and there have been many main reports and assessment reports such as those published in 1990, 1995, 2001, 2007, 2014, and 2016, 2018 [65], 2019 [66]. The IPCC sixth main assessment report has just been issued on 7 August 2021 but the document is subject to final copy-editing [67].

With commendable efforts, the "United Nations Framework Convention on

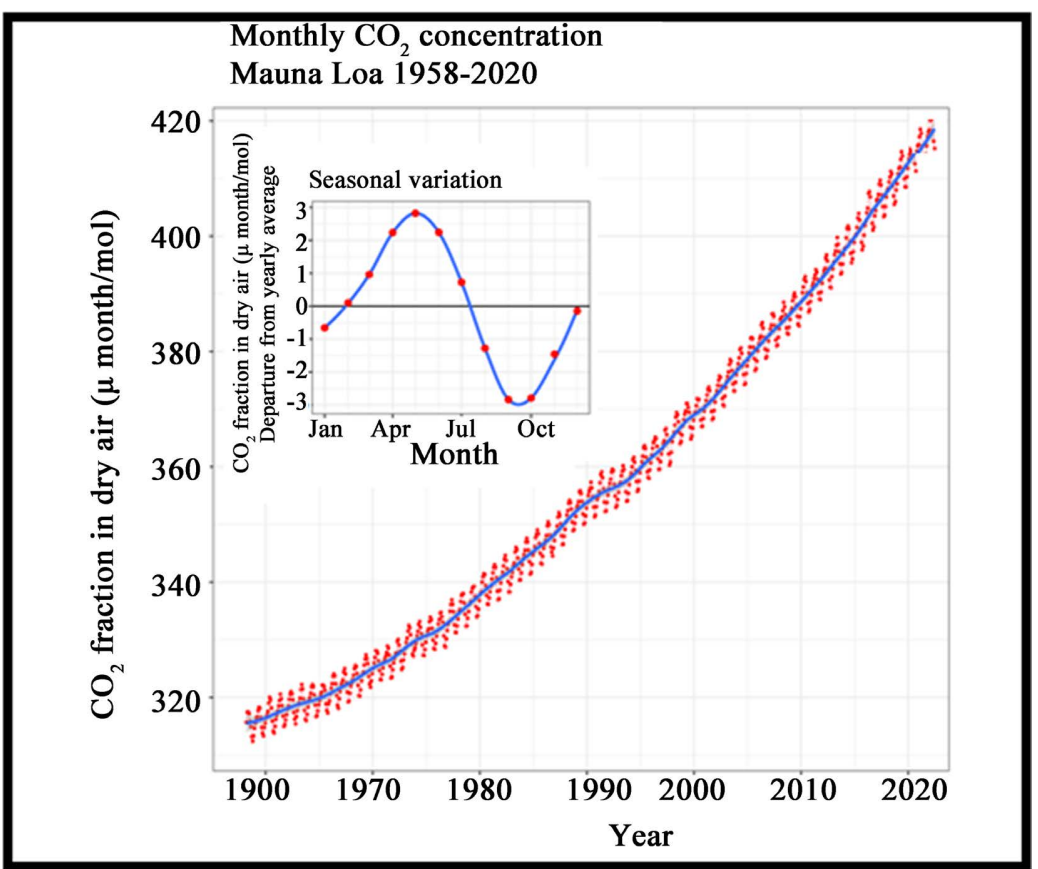

Figure 16. Atmospheric carbon dioxide $\left(\mathrm{CO}_{2}\right)$ concentrations from 1958 to 2019 [64]. 
Climate Change (UNFCCC)" was concluded in 1992, at the UN Rio Earth Summit [68]. This is formally a treaty but does not contain anything legally binding. Rather, it provides a framework for negotiating specific international treaties, and therefore all parties had met annually since 1995 under "Conferences of the Parties". The third meeting held in Kyoto in 1997 led to the signing of the "Kyoto Protocol" [69]. It aimed to add some power to the initial framework, with binding targets for greenhouse-gas reductions. There were high hopes for the fifteenth meeting in 2009 in Copenhagen but it was largely considered, at best, a disappointment [70].

The final breakthrough, however, was achieved by the conclusion of the Paris Accord [71]. The run-up to concluding this agreement started in July 2014 with talks continuing throughout 2015 until signing the agreement in April 2016. One hundred ninety-six countries agree to what experts call the most significant global climate agreement in history.

Unlike past accords, the Paris Agreement requires nearly all countries, both developed and developing, to set emissions reduction goals. However, countries can choose their targets and there are no enforcement mechanisms to ensure they meet them. Under the agreement, countries are supposed to submit targets known as nationally determined contributions.

The mission of the Paris Agreement, which entered into force in November 2016 , is to keep global temperature rise below $2^{\circ} \mathrm{C}$ and to stop it from rising above pre-Industrial Revolution level and pursue efforts to keep this rise below $1.5^{\circ} \mathrm{C}\left(2.7^{\circ} \mathrm{F}\right)$. However, analysts urge more action to achieve this goal [72]. But scientists caution that the effects of temperatures rising any higher would be catastrophic and potentially irreversible [73].

Great efforts have been made, so far, by governments and research Institutes, in the field of climate change and their future impacts on the environment mankind. It is felt, however, that there is need for much more research for better understanding for all involved phenomena, and for defining better mitigation measures and tools to be put in the hands of policy makers, for enhanced and purposeful actions, in order to keep global temperature, rise within manageable limits. The last National Climate Assessment report, released by the U.S. Global Change Research Program (USGCRP) in 2009, recommended the following fields of future required research:

1) Continue efforts to improve the understanding, modeling, and projections of climate changes, especially at the regional scale, including driving forces of emissions and land-use change, changes in temperature, precipitation, soil moisture, runoff, groundwater, evapotranspiration, permafrost, ice and snow cover, sea level change, and ocean processes and chemistry;

2) Improve characterization of important sources of uncertainty, including feedbacks and possible thresholds in the climate system associated with changes in clouds, land and sea ice, aerosols (tiny particles in the atmosphere), greenhouse gases, land use and land cover, emissions scenarios, and ocean dynamics; 
3) Develop indicators that allow for timely reporting and enhanced public understanding of climate changes and that allow anticipation and attribution of changes, including abrupt changes and extreme events in the context of a changing climate; and,

4) Advance understanding of the interactions of climate change and natural variability at multiple time scales, including seasonal to decadal changes (and consideration of climate oscillations including the El Niño Southern Oscillation, Pacific Decadal Oscillation, and the North Atlantic Oscillation), and extreme events (such as hurricanes, droughts, and floods) [74].

Although more than 12 years have passed since the issue of this report, the need still remains to do more research on the same lines, pursue the out-comes of this research, and enforce the necessary steps toward mitigating the climate change impacts, towards preserving our Planet; People and Environment.

\section{Conflicts of Interest}

The authors declare no conflicts of interest regarding the publication of this paper.

\section{References}

[1] National Geographical Society. Age of the Earth. https://www.nationalgeographic.org/topics/resource-library-age-earth/?q=\&page=1 \&per_page $=25$

[2] Goosse H., Barriat, P.Y., Lefebvre, W., Loutre, M.F. and Zunz, V. (2015) Chapter 5. Brief History of Climate: Causes and Mechanisms. In: Goosse H., Barriat, P.Y., Lefebvre, W., Loutre, M.F. and Zunz, V., Eds., Introduction to Climate Dynamics and Climate Modelling, Cambridge University Press, Cambridge, 109-144. https://oer.uclouvain.be/jspui/bitstream/20.500.12279/286/10/Chapter 5.pdf

[3] CiteSeerX (2020) Plate Tectonics-Climate Change. https://www.geo.umass.edu/climate/papers2/deconto tectonics\&climate.pdf

[4] Bristow, T. and Ford, T. (Editors) (2017) A Cultural History of Climate Change, Routledge, London, 224 p. https://doi.org/10.4324/9781315734590

[5] PMF IAS (2019) Phanerozoic Eon: Paleozoic Era, Mesozoic Era \& Cenozoic Era. https://www.pmfias.com/phanerozoic-eon-paleozoic-era-mesozoic-era-cenozoic-er a/\#Cambrian Period

[6] Wikipedia. Genus. https://en.m.wikipedia.org/wiki/Genus

[7] History.Com Editors (2021) Ice Age. https://www.history.com/topics/pre-history/ice-age

[8] Utah Geological Survey (2010) Glad You Asked Ice Ages; What Are They; What Causes Them. Survey Notes. https://issuu.com/utahgeologicalsurvey/docs/sn 42-3 sept2010

[9] Earle, S. (2019) Glacial Periods in Earth's History. In: Earle, S., Ed., Physical Geology, BCcampus, Victoria, BC. https://opentextbc.ca/geology/

[10] History. Com Editors (2021) How an Ice Age Changes Earth. https://www.history.com/topics/pre-history/ice-age

[11] Panchuk, K. (2019) Glaciation over Earth's History. Section 4, Chapter 17 of the 
Book (Physical Geology). The University of Saskatchewan, Saskatoon.

[12] Muller, R.A. and Jacobson, B. (2007) Physics and Technology for Future Presidents, Chapter 10 (Climate Change). Princeton University Press, Princeton.

[13] Aspen Global Change Institute (2020) Climate Change in the Prehistoric Era.

[14] McGregor, H., Gergis, J., Abram, N. and Phipps, S. (2016) The Industrial Revolution Kick-Started Global Warming Much Earlier than When We Realized. The Conversion Blogsite.

[15] Fox, J. (2020) Climate Change: Impacts of the Industrial Revolution. Landmark Academy.

[16] Scotese, C.R. (2016) Some Thoughts on Global Climate Change: The Transition for Icehouse to Hothouse Conditions. PALEOMAP Project.

https://www.researchgate.net/publication/275277369 Some Thoughts on Global Climate Change The Transition for Icehouse to Hothouse Conditions

[17] Wollersheim, L. (2017) What Is Climate Change and Global Warming and How Does It Affect Us. Extracts from the Book Climageddon: The Global Warming and How to Survive It.

https://www.joboneforhumanity.org/global warming?gclid=Cj0KCQiAhZT9BRDm ARIsAN2E-J1JPzm-EMxexrhpqKPPdFRjRvH8QdmCaNi5B8mk0V8FqnAtOy4rdQ EaAmTxEALw wcB

[18] Climate Policy Watcher (2021) The Warming Effects of the Industrial Revolution. https://www.climate-policy-watcher.org/global-temperatures/the-warming-effects-o f-the-industrial-revolution.html

[19] Cook, J. (2020) Why Did We Have Global Warming during the Industrial Revolution? Skeptical Science Blogspot.

[20] American Chemical Society (2020) What Are the Greenhouse Gas Changes since the Industrial Revolution?

https://www.acs.org/content/acs/en/climatescience/greenhousegases/industrialrevol ution.html

[21] Andrews K. (2016) What Causes an Ice Age and What Would Happen if the Earth Endured Another One? ABC Science.

[22] Houghton, L.G., Filho, M.B.A., Harris, C.N., Kattenberg, A. and Maskell, K. (1996) Climate Change 1995: The Science of Climate Change. Published for the Intergovernmental Panel on Climate Change. Cambridge University Press, Cambridge. https://www.ipcc.ch/site/assets/uploads/2018/02/ipcc sar wg I full report.pdf

[23] Lindsey, R. and Dahlman, L. (2021) Climate Change: Global Temperature. News \& Features.

https://www.climate.gov/news-features/understanding-climate/climate-change-glob al-temperature

[24] WMO (2020) FAQs-Climate. Commission of Climatology. https://public.wmo.int/en/about-us/frequently-asked-questions/climate

[25] UN (1992) United Nation Framework Convention on Climate Change. Page 3. https://unfccc.int/resource/docs/convkp/conveng.pdf

[26] Houghton, J.T., Jenkins, G.J. and Ephraums, J. (1990) Climate Change: The IPCC Scientific Assessment. Cambridge University Press, Cambridge, Page xxxvi. https://www.ipcc.ch/site/assets/uploads/2018/03/ipcc far wg I full report.pdf

[27] Solomon, S., Qin, D., Manning, M., Marquis, M., Averyt, K., Tignor, M.B., Miller, H.L. and Chen, Z. (2007) Climate Change: Understanding and Attributing Climate Change, the Physical Science Basis. Fourth Assessment Report. Cambridge Univer- 
sity Press, Cambridge, 10-11.

https://www.ipcc.ch/site/assets/uploads/2018/05/ar4 wg1 full report-1.pdf

[28] The United States Environment Protection Agency (2021) Overview of Greenhouse Gases. https://www.epa.gov/ghgemissions/overview-greenhouse-gases

[29] IPCC (2007) Projections of Future Changes in Climate. Climate Change 2007: Working Group I: The Physical Science Basis.

https://archive.ipcc.ch/publications and data/ar4/wg1/en/spmsspm-projections-of. $\underline{\mathrm{html}}$

[30] Adamo, N. and Al-Ansari, N. (2018) Climate Change Impacts: The Middle East and Iraq in Focus.

https://www.researchgate.net/publication/327690004 Climate Change Impacts Th e Middle East and Iraq in Focus

[31] Consortium for International Earth Science Information Network (CIESIN) (1996) General Circulation Models (GSMs). Thematic Guide to Integrated Assessment. https://sedac.ciesin.columbia.edu/mva/iamcc.tg/GCM thematic guide.html

[32] Sood, A. and Smakhtin, V. (2015) Global Hydrological Models: A Review. Hydrological Sciences Journal, 60, 549-565.

https://www.tandfonline.com/doi/pdf/10.1080/02626667.2014.950580 https://doi.org/10.1080/02626667.2014.950580

[33] Met Office (2020) Regional Climate Modelling. https://www.metoffice.gov.uk/research/climate/climate-impacts/regional-climate

[34] Takle, E.S. (2005) Regional Climate Modelling. Global Change Course. https://meteor.geol.iastate.edu/gccourse/model/regional/regional lecture new.html

[35] IPCC (2021) Climate Change Widespread, Rapid, and Intensifying, Climate Change 2021: The Physical Science Basis. Contribution of Working Group I to the Sixth Assessment Report of the Intergovernmental Panel on Climate Change. https://www.ipcc.ch/2021/08/09/ar6-wg1-20210809-pr/

[36] GreenFacts (2007) AOGCM Projections of Surface Temperatures. Climate Change 2007. http://www.greenfacts.org/en/climate-change-ar4/figtableboxes/figure-6.htm

[37] IPCC (2007) Projected Patterns of Precipitation Changes. IPCC Fourth Assessment Report: Climate Change.

https://archive.ipcc.ch/publications and data/ar4/wg1/en/figure-spm-7.html

[38] IPCC (2007) Multi-Model Mean Changes in Surface Air Temperature, Precipitation, and Sea Level Pressure for the SRES A1B Scenario (2080 to 2099) Relative to (1980 to 1999). IPCC Fourth Assessment Report: Climate Change 2007. https://archive.ipcc.ch/publications and data/ar4/wg1/en/figure-10-9.html

[39] Rajbhandari, R., Shrestha, A.B., Nepal, S. and Wahid, S. (2018) Projection of Future Precipitation and Temperature Change over the Transboundary Koshi River Basin Using Regional Climate Model PRECIS. Atmospheric and Climate Sciences, 8, 163 191. https://www.scirp.org/journal/PaperInformation.aspx?PaperID $=83763$

[40] Schmittner, A., Chiang, C.H.J. and Hemming, S.R. (2007) Introduction: The Ocean's Meridional Overturning Circulation. In: Schmittner, A., Chiang, J.C.H. and Hemming, S.R., Eds., Ocean Circulation: Mechanisms and Impacts, American Geophysical Union, Washington DC, 560.

https://books.google.se/books?hl=en\&lr=\&id=deylqS3WMOIC\&oi=fnd\&pg=PT11 \&dq=in+Ocean+Circulation:+Mechanisms+and+Impacts, + AGU+Geophysical+Mo nograph+Series, + vol. $+173 \&$ ots $=\mathrm{dz}$ E9arEBN\&sig=cBAttRK mMbVXA6AHYu9RI 0izzY\&redir esc $=\mathrm{y} \# \mathrm{v}=$ onepage $\& \mathrm{q} \& \mathrm{f}=$ false https://doi.org/10.1029/173GM02 
[41] UCAR Center for Science Education (2020) Ocean on the Move: Thermohaline Circulation. University Corporation for Atmospheric Research.

[42] Arctic Climate Emergency: Abrupt Climate Change. http://arcticclimateemergency.com/abrupt-climate-change/4559913919

[43] IPCC (2014) AR5 Climate Change 2014: Mitigation of Climate Chang. https://www.ipcc.ch/report/ar5/wg3/

[44] Bhattacharya, S. (2004) Global Warming Threatens Millions of Species. New Scientist.

https://www.newscientist.com/article/dn4545-global-warming-threatens-millions-o f-species/

[45] Mgbemene, C.A., Nnaji, C. and Nwozor, C.A. (2016) Industrialization and Its Backlash: Focus on Climate Change and its Consequences. Journal of Environmental Science and Technology, 9, 301-316.

https://docsdrive.com/pdfs/ansinet/jest/2016/301-316.pdf https://doi.org/10.3923/jest.2016.301.316

[46] IPCC (2014) Climate Change 2014: The Physical Science Basis: Contribution of Working Group I to the Fifth Assessment Report of the Intergovernmental Panel on Climate Change. Cambridge University Press, Cambridge.

[47] Klare, M. (2006) The Coming Resources War. Global Policy Forum.

[48] Medany, M. (2008) Impact of Climate Change on Arab Countries. Journal of Europe, 22,8 .

[49] Al-Ansari, N., Abbas, N., Laue, J. and Knutsson, S. (2021) Water Scarcity: Problems and Possible Solutions. Journal of Earth Sciences and Geotechnical Engineering, 11, 243-312. https://doi.org/10.47260/jesge/1127

[50] Al-Ansari, N., Abdellatif, M., Zakaria, S., Mustafa, Y. and Knutsson, S. (2014) Future Prospects for Macro Rainwater Harvesting (RWH), Technique in Northeast Iraq. Journal of Water Resource and Protection, 6, 403-420. https://doi.org/10.4236/jwarp.2014.65041

[51] Al-Ansari, N., Abdellatif, M., Ezeelden, M., Ali, S. and Knutsson, S. (2014) Climate Change and Future Long-Term Trends of Rainfall at Northeastern Part of Iraq. Journal of Civil Engineering and Architecture, 8, 790-805. https://doi.org/10.17265/1934-7359/2014.06.014

[52] Al-Ansari, N., Knutsson, S. and Almuqdadi, K. (2014) Engineering Solution for Radioactive Waste in Iraq. Journal of Advanced Science and Engineering Research, 4, 18-36.

[53] Al-Ansari, N.A. (2016) Hydro-Politics of the Tigris and Euphrates Basins. Engineering, 8, 140-172. https://doi.org/10.4236/eng.2016.83015

[54] Al-Ansari, N., Abdellatif, M., Ali, S. and Knutsson, S. (2014) Long Term Effect of Climate Change on Rainfall in Northwest Iraq. Central European Journal of Engineering, 4, 250-263. https://doi.org/10.2478/s13531-013-0151-4

[55] Al-Ansari, N., Mohammad, E.M., Knutsson, S. and Zakaria, S. (2013) Water Harvesting and Reservoir Optimization in Selected Areas of South Sinjar Mountain, Iraq. Journal of Hydrologic Engineering, 18, 1607-1616. https://doi.org/10.1061/(ASCE)HE.1943-5584.0000712

[56] Al-Ansari, N. (2013) Management of Water Resources in Iraq: Perspectives and Prognoses. Engineering, 5, 667-684. https://doi.org/10.4236/eng.2013.58080

[57] USAID (2017) Climate Change Risk Profile, Iraq. https://www.climatelinks.org/sites/default/files/asset/document/2017Mar3 GEMS 
Climate\%20Risk\%20Profile Iraq_FINAL.pdf

[58] Abbas, N., Wasimi, S.A. and Al-Ansari, N. (2020) Impacts of Climate Change on Water Resources of Fitzroy River and Tigris River Basins and Identification of Adaptation Measures. Ph.D. Thesis, University of Central Queensland, Norman Gardens.

[59] Abd-Elmooty M., Kansoh R. and Abdulhadi A. (2016) Challenges of Water Resources in Iraq. Hydrology: Current Research, 7, 1-8.

[60] Al-Monitor (2021) Water Crisis Puts 12 Million at Risk in Syria, Iraq, Aid Groups Say.

[61] UN Office for the Coordination of Humanitarian Affairs (OCHA) (2021) Water Crisis and Drought Threaten More than 12 Million in Syria and Iraq. https://reliefweb.int/report/syrian-arab-republic/water-crisis-and-drought-threaten -more-12-million-syria-and-iraq

[62] UN Office for the Coordination of Humanitarian Affairs (OCHA) (2021) Syrian Arab Republic, Euphrates Water Crisis \& Drought Outlook.

https://reliefweb.int/sites/reliefweb.int/files/resources/Syrian\%20Arab\%20Republic \%20-\%20Euphrates\%20water\%20crisis\%20and\%20drought\%20outlook\%2C\%20as \%20of\%2017\%20June \%202021.pdf

[63] Bani Salameh, M.T., Alraggad, M. and Harahsheh, S.T. (2021) The Water Crisis and the Conflict in the Middle East. Sustainable Water Resources Management, 7, Article No. 69. https://doi.org/10.1007/s40899-021-00549-1

[64] Wikipedia. Keeling Curve. https://en.wikipedia.org/wiki/Keeling Curve

[65] IPCC (2018) Global Warming of $1.5^{\circ} \mathrm{C}$ : Summary for Policymakers. Special Report on the Impacts of Global Warming of $1.5^{\circ} \mathrm{C}$ above Pre-Industrial Levels and Related Global Greenhouse Gas Emission Pathways, in the Context of Strengthening the Global Response to the Threat of Climate Change, Sustainable Development, and Efforts to Eradicate Poverty.

https://www.ipcc.ch/site/assets/uploads/sites/2/2018/07/SR15 SPM version stand alone LR.pdf

[66] IPCC (2019) Climate Change and Land: An IPCC Special Report on Climate Change, Desertification, Land Degradation, Sustainable Land Management, Food Security, and Greenhouse Gas Fluxes in Terrestrial Ecosystems. Summary for Policymakers. https://www.ipcc.ch/site/assets/uploads/2019/08/Fullreport-1.pdf

[67] IPCC (2021) Climate Change 2021-The Physical Basis. https://www.ipcc.ch/report/ar6/wg1/downloads/report/IPCC AR6 WGI Full Rep ort.pdf

[68] UN (1992) United Nations Framework Convention on Climate Change. https://unfccc.int/files/essential background/background publications htmlpdf/ap plication/pdf/conveng.pdf

[69] UN (2008) Kyoto Protocol Reference Manual on Accounting of Emissions and Assigned Amount.

https://unfccc.int/resource/docs/publications/08 unfccc kp ref manual.pdf

[70] UN (2021) Climate Change. Copenhagen Climate Change Conference. https://unfccc.int/process-and-meetings/conferences/past-conferences/copenhagenclimate-change-conference-december-2009/copenhagen-climate-change-conference -december-2009

[71] UN (2015) UN Paris Agreement. https://unfccc.int/files/essential background/convention/application/pdf/english p aris agreement.pdf 
[72] Council on Foreign Relations (2020) 2015 Landmark Paris Agreement Reached. UN Climate Talks 1992-2020.

[73] World101. Global Era Issues. The Paris Agreement.

[74] Kirstin Dow, K., Kristie, L., Kunkel, K., Mearns, L.O., National Center for Atmospheric Research and Melillo, J. (2014) Research Needs for Climate and Global Change Assessments. National Climate Assessment. U.S. Global Change Research Program.

https://nca2014.globalchange.gov/report/response-strategies/research-needs 